\section{Identifying Rose Cultivars Using Random Amplified Polymorphic DNA Markers}

\author{
A.M. Torres \\ Departamento de Mejora y Agronomía, Centro de Investigación y Desarrollo \\ Agrario, Apartado 4240, 14080 Córdoba, Spain
}

T. Millán and J.I. Cubero

Departamento de Genética, Escuela Tecnica Superior de Ingenieros Agrónomos y de Montes, Apartado 3048, 14080 Córdoba, Spain

Additional index words. Rosa hybrids, random amplified polymorphic DNA markers, cultivar identification, patent protection

Abstract. Five rose (Rosa spp.) cultivars were analyzed using random amplified polymorphic DNA (RAPD) markers. Using eight primers, all cultivars were distinguished by comparing differences in DNA banding patterns. The RAPD technique fingerprints rose cultivars rapidly and inexpensively for identification and patent protection purposes.

Developing highly reliable and discriminatory methods for identifying cultivars has become increasingly important to plant breeders and those in the nursery industry who need sensitive tools to differentiate among and identify cultivars for plant patent protection. In the past, cultivars were identified primarily based on horticultural, morphological, and physiological descriptions. In most cases, the descriptions and measurements varied considerably due to environmental fluctuation and human judgment. The development of new cultivars that lack distinguishing morphological characteristics has furthered the need for more positive identification methods. As an adjunct to morphological and physiological methods, identification tests based on isozyme patterns have been introduced to fingerprint ornamentalcultivars of various species (Kuhns and Fretz, 1978; Messeguer and Arús, 1985; Wendel and Parks, 1983). This technique, however, is not powerful enough to distinguish among phenotypically similar cultivars. Tissue must be sampled at comparable physiological states to obtain uniform and repeatable banding patterns. Moreover, some genetic differences among cultivars may not be visualized by isozyme technique, since the number of loci that can be resolved is limited.

Methods developed over the past 20 years can detect differences in DNA sequence between individuals. Compared to isozyme techniques, analyzing DNA has many advantages: it is independent of environmental conditions; DNA sequence is identical, no matter what

Received for publication 5 Aug. 1992. Accepted for publication 28 Dec. 1992. This research has been performed within the framework of the Andalusian Biotechnology Institute (Instituto Andaluz de Biotecnología). The cost of publishing this paper was defrayed in part by the payment of page charges. Under postal regulations, this paper therefore must be hereby marked advertisement solely to indicate this fact. plant tissue or tissue stage is analyzed; and the number of scorable loci is unlimited. The most widely used technique is restriction fragment length polymorphism (RFLP) analysis. Base substitutions in a restriction endonuclease site or insertions or deletions between sites result in detectable differences in the fragment length of restriction enzyme-digested DNA. These polymorphisms already have helped identify cultivars of some species (Apuya et al., 1988; Gebhardt et al., 1989), includingrose (Hubbard et al., 1992). More recently, the random amplified polymorphic DNA (RAPD) technique (Williams et al., 1990) based on the polymerase chain reaction (PCR) has been used to detect polymorphism in some species (Welsh and McClelland, 1990, Welsh et al., 1991; Williams et al., 1990). The technique involves using a single primer $\approx 10$ bases long to generate fingerprints of DNA segments that amplify in DNA preparations from one parent but not the other. Detected polymorphisms are inherited in a Mendelian fashion and can be produced from any species without any other DNA sequence information (Williams et al., 1990). The RAPD technique has similar uses as RFLP analysis--constructing linkage maps, identifying cultivars, and determining parentage are among the most valuable applications (Welsh et al., 1991). Advantages of the RAPD technique over RFLP analysis include the following: 1) the equipment and supplies necessary are inexpensive relative to those needed for RFLP analysis; 2) speed of analysis is <2 days, since Southern blotting and labeled probes are not necessary; 3) minimal quantities of DNA are required; and 4) a high degree of polymorphism is generated when the RAPD technique is used, a result indicating that selecting lines with diverse genetic backgrounds may be less critical than when using RFLP analysis (Weeden, 1991; Williams et al., 1990).

The objective of the present study was to assess the discriminating power of RAPD markers to identify and protect rose cultivar patents. For this purpose, we surveyed variability patterns produced with eight primers and five rose cultivars. Samples of the following cultivars were provided by Universal Plantas S.A. of Sevilla, Spain: 'Cardinal' (A), 'Sonia' (B), 'Carta Blanca' (C), 'Laser' (D), and 'Carta de Oro' (E). DNA of each cultivar was extracted from $\approx 100 \mathrm{mg}$ of young, unexpanded or partially expanded leaf tissue, because this tissue produced the highest DNA yield. Leaves were stored at $-80 \mathrm{C}$ if not used immediately. The extraction procedure was as described by Torres et al. (1993), a method based on (but considerably modified from) that of Lassner et al. (1989). Coprecipitated RNA was eliminated by adding 0.7 units of RNase A. The DNA was dissolved in trisEDTA, and the final concentration was estimated by agarose gel electrophoresis and ethidium staining, using known concentrations of uncut $\lambda$ DNA as a standard. To check the repeatability of the fingerprint pattern, more than one plant (in most cultivars) was included in the analysis. Thus, a total of 10 plants was-analyzed.

Primers and amplification conditions. Eight 10-base-long arbitrary primers (Operon Technologies, Alameda, Calif.) were used for the experiments (Table 1). DNA amplification conditions were standardized for all primers. Amplification reactions were performed in 25 $\mu \mathrm{l}$ of 20 to $40 \mathrm{ng}$ of plant genomic DNA, buffer [50 mm KC1, $10 \mathrm{~mm}$ tris- $\mathrm{HCl}$ (pH 8.3), $1.5 \mathrm{~mm}$ $\mathrm{MgCl}_{2}$, and $0.001 \%$ gelatin], and $100 \mu \mathrm{m}$ each of dNTP, $0.2 \mu \mathrm{M}$ primer, and 1 unit Taq DNA polymerase (Promega, Madison, Wis.). The reaction was overlaid with mineral oil. Amplification was performed in a Perkin Elmer (Norwalk, Conn.) Cetus DNA Thermal Cycler programmed for 40 cycles with the following temperature profile: $1 \mathrm{~min}$ at $94 \mathrm{C}, 2 \mathrm{~min}$ at $35 \mathrm{C}$, and $2 \mathrm{~min}$ at $72 \mathrm{C}$, using the fastest available transitions between each temperature. Cycling ended with a final extension at $72 \mathrm{C}$ for $8 \mathrm{~min}$. Amplification products were electrophoresed in $1 \%$ agarose, $1 \% \mathrm{Nu}$-Sieve (FMC BioProducts, Rockland, Maine) agarose, and $1 \times$ tris-borate-EDTA gels and visualized by ethidium staining. Controls lacking template DNA were included on each primer reaction mix used.

Cultivar comparisons. Identifying cultivars by the RAPD technique is possible because each cultivar yields a reproducible DNA band pattern. Since a limitless number of primers can be assayed and several DNA bands can be differentiated for each one. the number of

Table 1. Sequence of the eight oligonucleotide primers used [primer identification (ID) following OPERON's recommendations].

\begin{tabular}{lc}
\hline Primer ID & $\begin{array}{c}\text { Sequence } \\
\left(5^{\prime} \text { to } 3^{\prime}\right)\end{array}$ \\
\hline OPA-01 & CAGGCCCTTC \\
OPA-02 & TGCCGAGCTG \\
OPA-03 & AGTCAGCCAC \\
OPA-04 & AATCGGGCTG \\
OPA-05 & AGGGGTCTTG \\
OPA-06 & GGTCCCTGAC \\
OPA-07 & GAAACGGGTG \\
OPA-08 & GTGACGTAGG \\
\hline
\end{tabular}


possible combinations is infinite. In the present work, differences among cultivars were obvious and expressed consistently with most primers. The most discriminatory primers were OPA-06 (Fig. 1) and OPA-08 (Fig. 2), which gave clear differences in banding patterns among cultivars. Discriminatory bands are indicated by arrows in the corresponding figures. For example, using OPA-06, 'Sonia' was discriminated from all other cultivars by the simultaneous presence of two intense bands of $\approx 950$ and $1100 \mathrm{bp}$, while 'Carta Blanca' exhibited the 950-bp band and a band of $\approx 800 \mathrm{bp}$ (Fig. 1). The remaining cultivars were charac- terized by 1) a combination of four bands ranging between $\approx 1250$ and 950 bp ('Laser'); 2) three bands of $\approx 800,1100$, and $1150 \mathrm{bp}$ ('Carta de Oro'); and 3) three bands of 950, 1100, and 1250 bp ('Cardinal') (Fig. 1). OPA08 gave similar results (Fig. 2). With all primers, the DNA banding pattern for each cultivar was consistent. Occasional differences in the intensity of some nondiscriminatory bands between replicates of the same cultivar (e.g., 'Laser' in Figs. 1-3) probably were due to differences in the quality of DNA isolated from the respective samples. The remaining primers gave less conclusive results. OPA-05

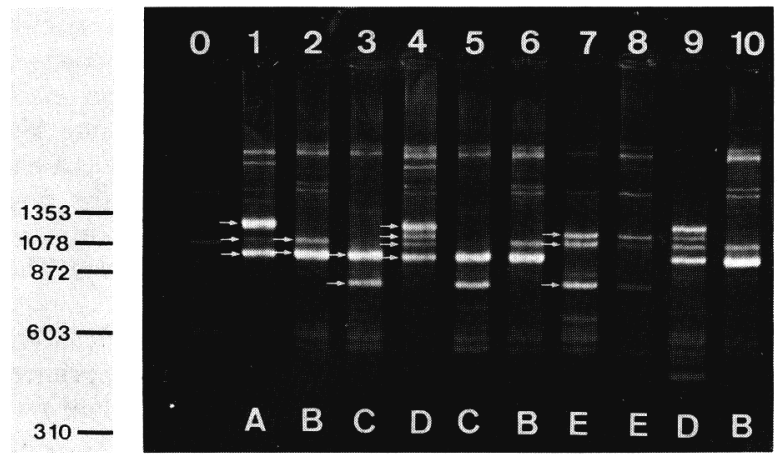

Fig. 1. Amplifying rose cultivar DNA using the OPA-06 primer: (A) 'Cardinal' (lane 1), (B) 'Sonia' (lanes 2,6, and 10), (C) 'Carta Blanca' (lanes 3 and 5), (D) 'Laser' (lanes 4 and 9), and (E) ‘Carta de Oro' (lanes 7 and 8 ). Lane $0=$ control sample lacking template DNA. Discriminatory bands among cultivars are indicated by arrows. Size marker was derived from $\emptyset x 174 /$ Hind III digest.

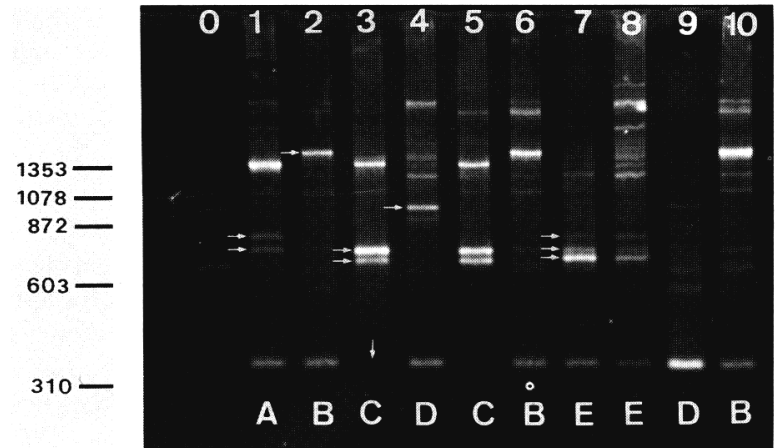

Fig. 2. Amplifying rose cultivar DNA using the OPA- 08 primer. Cultivar designations and corresponding lanes are the same as given in Fig. 1. Discriminatory bands among cultivars (or their absence) are indicated by arrows. Size marker was derived from $\emptyset$ x174/Hind III digest.

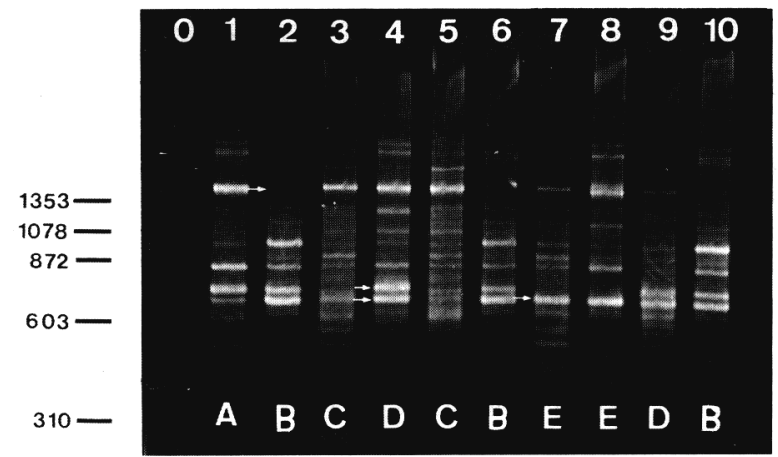

Fig. 3. Amplifying rose cultivar DNA using the OPA-05 primer. Cultivar designations and corresponding lanes are the same as given in Fig. 1. Discriminatory bands among cultivars (or their absence) are indicated by arrows. Size marker was derived from $\emptyset \times 174 /$ Hind III digest.

(Fig. 3) clearly distinguished 'Sonia' (B), 'Carta Blanca' (C), 'Laser' (D), and 'Carta de Oro' (E), but 'Cardinal' (A) could not be distinguished from 'Laser'. OPA-04 was the only primer that failed to amplify rose genomic DNA and displayed faint, inconsistent bands; hence, OPA-04 was not considered in the analysis. The rest of the primers (Table 1) consistently identified 'Sonia', 'Carta Blanca', and 'Carta de Oro', but 'Cardinal' and 'Laser' were sometimes ambiguously classified (data not shown).

Although additional work is needed to confirm the results obtained in this initial study, our results indicate that the RAPD technique can characterize rose cultivars. This method offers a rapid and relatively inexpensive way to resolve many highly discriminatory bands, thus increasing the probability of correctly identifying cultivars to protect patent rights.

\section{Literature Cited}

Apuya, R., B. Frazier, P. Keim, E.J. Roth, and K. Lark. 1988. Restriction fragment length polymorphisms as genetic markers in soybean, Glycine max (L.) Merril. Theoretical Applied Genet. 75:889-901.

Gebhardt, C., C. Glomendahl, U. Schachtschabel, T. Debener, F. Salamini, and E. Ritter. 1989. Identification of $2 \mathrm{n}$ breeding lines and $4 \mathrm{n}$ varieties of potato (Solanum tuberosum ssp. tuberosum) with RFLP-fingerprints. Theoretical Applied Genet. 78:16-22.

Hubbard, M., J. Kelly, S. Rajapakse, A. Abbott, and R. Ballard. 1992. Restriction fragment length polymorphisms in rose and their use for cultivar identification. HortScience 27:172-173.

Kuhns, L.J. and A.T. Fretz. 1978. Distinguishing rose cultivars by polyacrylamide gel electrophoresis. II. Isoenzyme variation among cultivars. J. Amer. Soc. Hort. Sci. 103:509-516.

Lassner, M.W., P. Peterson, and J.I. Yoder. 1988 Simultaneous amplification of multiple DNA fragments by polymerase chain reaction in the analysis of transgenic plants and their progeny. Plant Mol. Biol. Rptr. 7:116-128.

Messeguer, R. and P. Arús. 1985. Electrophoretic identification of carnation cultivars. HortScience 20:372-373.

Torres, A.M., N.F. Weeden, and A. Martin. 1993. Linkage between isozymes, RFLP and RAPD markers in Vicia faba. Theoretical Applied Genet. 85:937-945

Weeden N.F. 1991. Chromosomal organization and gene mapping, p. 23-49. In: D. Murray (ed.). Advanced methods in plant breeding and biotechnology. CAB Intl., Wallingford, U.K.

Welsh, J., R.J. Honeycutt, M. McClelland, and B.W.S. Sobral. 1991. Parentage determination in maize hybrids using the arbitrarily primed polymerase chain reaction (AP-PCR). Theoretical Applied Genet. 82:473-476.

Welsh, J. and M. McClelland. 1990. Fingerprinting genomes using PCR with arbitrary primers. Nucleic Acid Res. 18:7213-7218.

Wendel, J.F. and C.R. Parks. 1983. Cultivar identification in Camellia japonica L. using allozyme polymorphisms. J. Amer. Soc. Hort. Sci. 108:290-295.

Williams, J.G.K., A.R. Kubelik, K.J. Livak, J.A. Rafalski, and S.V. Tingey. 1990. DNA polymorphism amplified by arbitrary primers as useful as genetic markers. Nucleic Acid Res. 18:6531-6535. 